\title{
Evaporite mineral assemblages in the nakhlite (martian) meteorites
}

\author{
J.C. Bridges*, M.M. Grady \\ Department of Mineralogy, Natural History Museum, London SW7 5BD, UK
}

Received 28 July 1999; accepted 19 January 2000

\begin{abstract}
A mineralogical study of the three nakhlite (martian) meteorites has revealed that they contain evaporite mineral assemblages. Lafayette has Ca-siderite and clay minerals (smectite/illite) along fractures within olivine; Governador Valadares contains clay mineral veins in olivine, with siderite, gypsum and anhydrite in interstitial areas; Nakhla has clay and gypsum veins in olivine, with $\mathrm{Mg}$-, Mn-rich siderite, anhydrite and halite in interstitial sites. Minor goethite is also present in the three meteorites. Lafayette siderite has the range of compositions $\left(\mathrm{mol}^{\%}\right) \mathrm{CaCO}_{3} 21.6-36.8, \mathrm{MnCO}_{3}$ 4.2-35.3, $\mathrm{MgCO}_{3}$ 0.1-1.6, $\mathrm{FeCO}_{3}$ 27.4-67.0; Governador Valadares has $\mathrm{CaCO}_{3}$ 3.6-11.1, $\mathrm{MnCO}_{3} 1.1-2.1, \mathrm{MgCO}_{3}$ 9.0-29.2, $\mathrm{FeCO}_{3}$ 64.3-77.8; Nakhla has $\mathrm{CaCO}_{3}$ 0.1-5.7, $\mathrm{MnCO}_{3}$ 1.0-39.9, $\mathrm{MgCO}_{3}$ 2.0-40.9, FeCO 23.2-87.0. Trace element abundances for clay, siderite and gypsum are all similar with LREE, Y $>\mathrm{HREE}, \mathrm{Zr}, \mathrm{Nb}$ and La 0.9-95 $\times$ CI; Y $0.2-2.4 \times$ CI. This pattern of abundances reflects the trace element contents of the parent fluid, which in turn were derived through dissolution of LREE-enriched feldspathic mesostasis. The close similarities in silicate petrography and radiometric ages determined by other workers for these olivine clinopyroxenites suggests that the parent rocks were close to one another on Mars and therefore the same fluid may have been responsible for the precipitation of the evaporite mineral assemblages. Lafayette contains the mineral assemblage and siderite composition which are least soluble in water and Nakhla contains the most soluble minerals and carbonate composition. On the basis of our new data we consider a new model of progressive evaporation from a $\mathrm{Na}-\mathrm{Mg}-\mathrm{Fe}-\mathrm{Ca}-\mathrm{SO}_{4}-\mathrm{Cl}-\mathrm{H}_{2} \mathrm{O}-\mathrm{HCO}_{3}^{-}$acidic brine in an area of enclosed drainage (e.g. crater or low-lying flood plain) on Mars. Partial dissolution of near-surface rocks by the acidic brine released $\mathrm{Fe}, \mathrm{Mg}$ and trace elements from mesostasis and olivine into the fluid. The Lafayette assemblage was formed where $>25 \%$ volume of the water remained following evaporation, Governador Valadares $20 \%$ and Nakhla $<10 \%$. This model is consistent with martian ground temperatures at $>0{ }^{\circ} \mathrm{C}$ and a thicker atmosphere $\left(\mathrm{pCO}_{2}=30-100\right.$ mbar) at least over brief periods of time $\leq 1.3 \mathrm{Ga}$. (C) 2000 Elsevier Science B.V. All rights reserved.
\end{abstract}

Keywords: evaporites; mineral assemblages; Mars; nakhlite

\section{Introduction}

The three nakhlites - Nakhla, Governador Va-

* Corresponding author. E-mail: jcb@nhm.ac.uk ladares and Lafayette - form a closely similar clan within the SNC (Shergottite-Nakhlite-Chassignite) group of meteorites. The $\mathrm{SNC}$ meteorites define a group on the oxygen 3 isotope plot indicating derivation from a common parent body $[1,2]$. This parent body is widely believed to be Mars on the basis of the SNC group's long range 
of ages, fractionated bulk and trace element compositions, relatively oxidised mineral assemblages and trapped gas compositions [3-5]. Nakhla is an observed fall (1911) and the other two are finds of more uncertain origin. Despite their similarities, there are sufficient visual, petrographic and chemical differences to distinguish between the meteorites [6-8]. No evidence of terrestrial weathering in these meteorites has been reported.

The nakhlites are olivine clinopyroxenites (augite with minor orthopyroxene) with interstitial glass, feldspar and a silica polymorph. Ti-rich magnetite and ilmenite grains are also common. The mesostasis in Nakhla and Governador Valadares is glassier than that of Lafayette, which has undergone more extensive compositional equilibration than the other two meteorites [7]. The parent rocks may have formed through melt differentiation and augite accumulation within a thick basic-ultrabasic lava flow or shallow intrusion similar to some Archaean flows on Earth [9]. It is likely that the three meteorites formed in the same igneous event at the same locality. The melt source was LREE-depleted mantle, and crystallisation of the Nakhlites took place at $1.3 \mathrm{Ga}(\mathrm{Ar}-$ $\mathrm{Ar}, \mathrm{Rb}-\mathrm{Sr}$; Sm-Nd) $[4,10,11]$. The three nakhlites have ejection ages of 11.0 Ma [12].

The shallow, crustal origin of the nakhlites makes them of particular interest in tracing the effects of interaction between crustal fluids and the surface igneous rocks on Mars. As we argue in this paper, their mineralogical assemblages can also provide information about the nature of sedimentary processes on the planet. The presence of smectite/illite veins within olivine $[8,13,14]$ is the clearest evidence for low temperature aqueous activity in the parent rocks. These veins are in places seen to be truncated by fusion crust and so clearly have a preterrestrial, martian origin. Carbonate minerals in the SNC meteorites can reveal infor- mation about crustal and atmospheric reservoirs on Mars. For instance, siderite in Nakhla has Cisotopic compositions $\leq \delta^{13} \mathrm{C}+50 \%$ [15] that may have resulted from exchange between a ${ }^{13} \mathrm{C}$-rich atmosphere and fluids from which the carbonate or its sedimentary precursors precipitated. Similarly, siderite in Nakhla and Lafayette has $\delta^{18} \mathrm{O}=+31-36 \%$ o [16,17], which may indicate exchange with ${ }^{18} \mathrm{O}$-rich fluids.

The aim of this paper is to describe and compare the salt mineral assemblages (siderite, sulphate, chlorapatite, halite) present in the three nakhlites and propose a model for their formation. The nakhlites are characterised by the presence of significant amounts of siderite, first noted in Nakhla by Carr et al. and Chatzitheodoris and Turner [18,19]. Bridges and Grady [20] described an evaporite-like halite-siderite-anhydrite-chlorapatite assemblage in Nakhla. Siderite has also been noted in Lafayette [17]. Previously [20], we have proposed a high temperature origin for the salt assemblage in Nakhla by assimilation of evaporites into the melts. This model was based mainly on the unusual textures seen at high magnification, e.g. juxtaposition of siderite with pyroxene. Soil or sediment contamination of the nakhlite melts may be the explanation for some of the geochemical characteristics of these meteorites such as high ${ }^{129} \mathrm{Xe}$ abundances [21]. Here we explore an alternative model for the three nakhlites of low temperature precipitation from brines. Such a model has been proposed for the ankeritic carbonates in the SNC meteorite ALH84001 [22,23]. Determination of the nature of aqueous and sedimentary processes on Mars is important for understanding the geological history of the planet. This includes determining the current sites for some of the $\mathrm{C}$ and $\mathrm{H}_{2} \mathrm{O}$ which were present in a thicker atmosphere in earlier epochs [24]. It is also important in making the

Fig. 1. Back-scattered electron images of the evaporite mineral assemblages of the nakhlites. (A) Lafayette. (B-E) Governador Valadares. (F) Nakhla. (A) Siderite and smectite/illite clay vein in fractures within olivine. (B) Siderite grain within interstitial mesostasis. This grain also encloses a lamella of ilmenite. (C) A magnetite-ulvöspinel grain encloses feldspathic glass and two grains of siderite. The outline of the larger siderite grain is similar to the fracture outlines in A suggesting a similar origin. (D) Goethite veins gypsum, a silica polymorph and plagioclase. The goethite in the lower part of the photo is replacing magnetite. (E) Gypsum vein within olivine. (F) Halite segregation in between augite grains. $\mathrm{Ol}=$ olivine, $\mathrm{sd}=$ siderite, $\mathrm{a}=\mathrm{augite}, \mathrm{pl}=\mathrm{plagio}-$ clase, $\mathrm{il}=$ ilmenite, $\mathrm{fp}=$ feldspathic glass, $\mathrm{m}=$ magnetite, $\mathrm{gt}=$ goethite, $\mathrm{py}=$ pyrite, $\mathrm{sa}=$ silica polymorph, $\mathrm{gy}=\mathrm{gypsum}, \mathrm{h}=\mathrm{halite}$. 

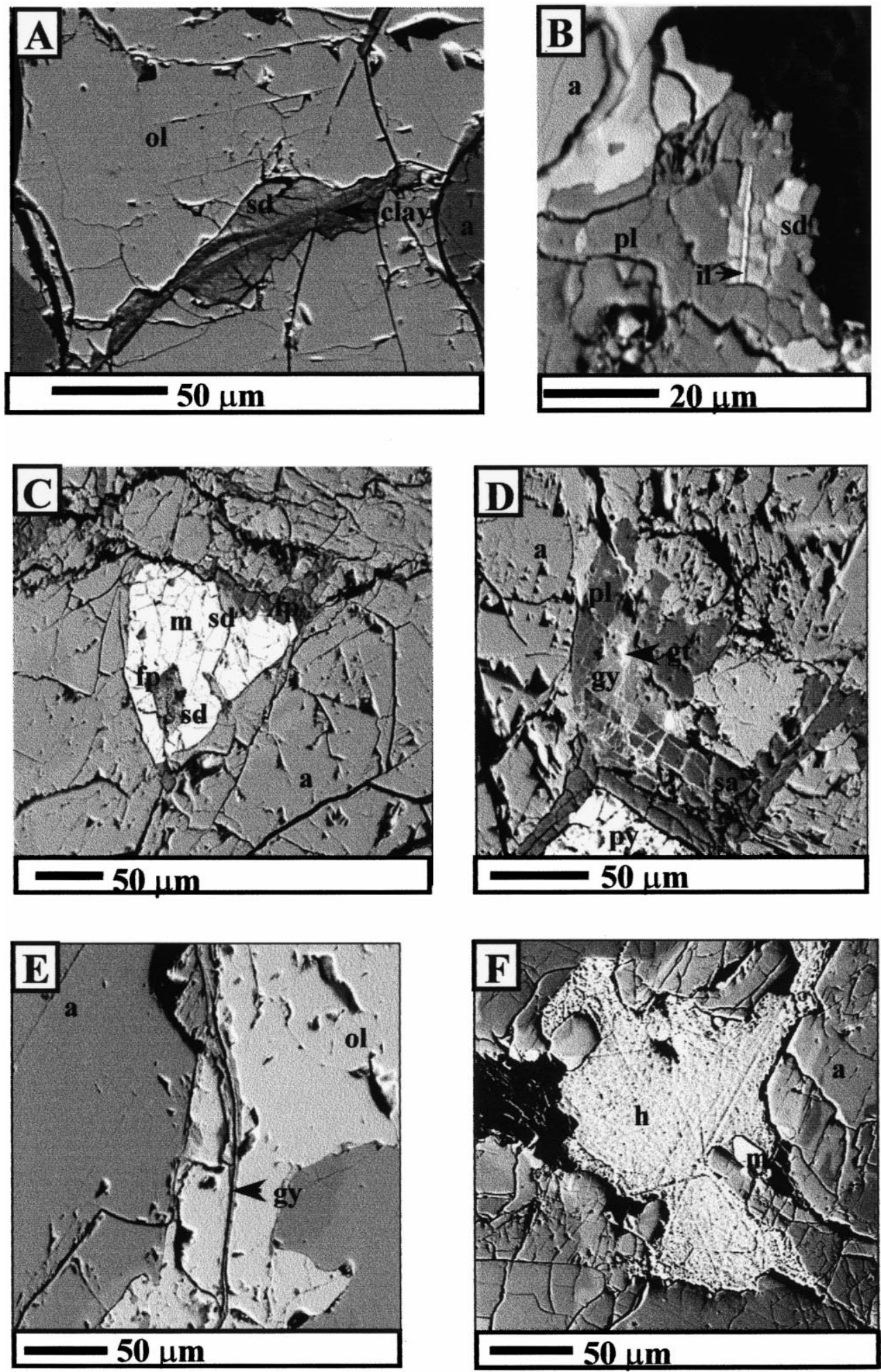
Table 1

Summary of evaporite mineral assemblages

\begin{tabular}{lll}
\hline Meteorite & Minerals & Carbonate \\
\hline Lafayette & Goeth, sm/ill, ap & Ca-rich siderite \\
G. Valadares & Goeth, sm/ill, ap, gyp, anhyd & siderite \\
Nakhla & Goeth, sm/ill, ap, gyp, anhyd, halite, Mg-SO a & $\mathrm{Mg}$-, Mn-rich siderite \\
\hline
\end{tabular}

Goeth $=\mathrm{Cl}$ bearing goethite, $\mathrm{sm} / \mathrm{ill}=$ smectite/illite veins, $\mathrm{ca}=$ chlorapatite of igneous or low temperature origin, gyp $=$ gypsum, anhyd $=$ anhydrite.

${ }^{\text {a }}$ Reported by [14].

selection of landing sites $[25,26]$ in environments where traces of any life may have been preserved.

\section{Samples and methods}

Governador Valadares (sample BM 1975, M16), Lafayette (BM 1959, 755) and Nakhla (BM 1911 369; BM 1913, 26) were used in this work. Apart from one thin section of Governador Valadares which was prepared with water, the sections/blocks used in this study were polished in oil and cleaned with non-polar solvents in order to minimise the loss of water soluble phases. Two polished sections or blocks of Governador Valadares, three of Lafayette and 16 of Nakhla were examined, mainly with back-scattered electron images. Except for clay minerals, all of the minerals discussed here were analysed with a $\mathrm{Ca}-$ meca SX50 at $12 \mathrm{kV}, 10 \mathrm{nA}$. A slightly defocused beam $(3 \mu \mathrm{m})$ was used in the case of those phases, including carbonate, liable to instability during analysis. The clay mineral veins were analysed with a Hitachi $2500 \mathrm{SEM}$ at $15 \mathrm{kV}$ and $2 \mathrm{nA}$ specimen current.

Trace element analyses of six siderite grains, one chlorapatite and three clay mineral veins from Lafayette together with two siderite and one gypsum from Governador Valadares were determined with a Cameca IMS 4f ion microprobe. Analyses were made using a ${ }^{16} \mathrm{O}$ beam of $15 \mathrm{keV}$ net impact energy and beam current of 4-5 nA. The beam diameter was approximately $15 \mu \mathrm{m}$. Energy filtering (secondary ion energies limited to $75 \pm 20 \mathrm{eV}$ ) was used to reduce the molecular ion species and corrections were made for known molecular ion overlaps ( $\mathrm{BaO}$ and light REE oxides on $\mathrm{Eu}$ and heavy REE and FeSi on $\mathrm{Rb}$ ). The main standard was SRM 610 silicate glass and secondary standards of Durango and Wilberforce apatite, relative count rates are accurate. The very low concentrations are limited by counting statistics to $1 \sigma$ standard deviations of $50-70 \%$ at 0.01 ppm, $15-20 \%$ at $0.1 \mathrm{ppm}$ and $5 \%$ at $1 \mathrm{ppm}$. Previous trace element analyses on siderite and anhydrite in Nakhla used the same technique and operating conditions and these are reported in [20]. Qualitative indications of $\mathrm{H}_{2} \mathrm{O}$ presence in some of the sample grains were obtained using measured $\mathrm{H}^{+}$counts.

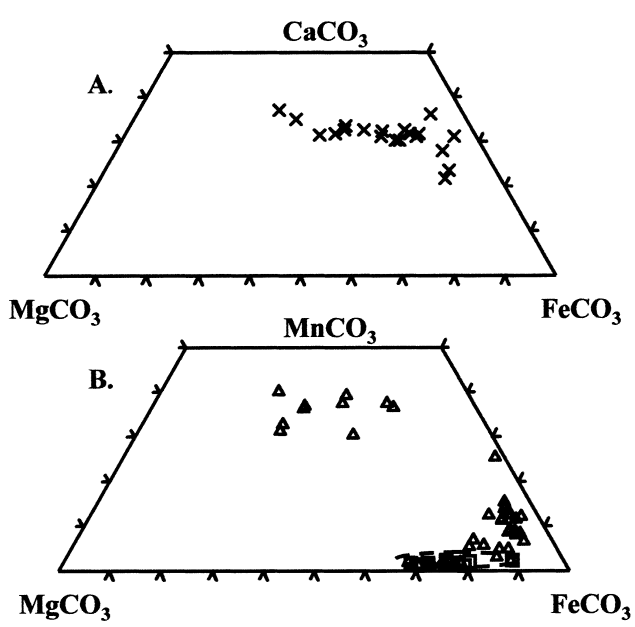

Fig. 2. Composition $\left(\mathrm{mol}^{\%} \mathrm{)}\right)$ of carbonate in the nakhlites. (A) $\mathrm{Ca}-\mathrm{Mg}-\mathrm{FeCO}_{3}$ of Lafayette $(n=20)$. (B) $\mathrm{Mn}-\mathrm{Mg}$ $\mathrm{FeCO}_{3}$ of Governador Valadares (open squares within dashed ellipse, $n=12)$ and Nakhla $(n=41$, triangles). Nakhla data from [20]. 
Table 2

Electron microprobe analyses $(\mathrm{wt} \%)$

\begin{tabular}{|c|c|c|c|c|c|c|c|c|c|c|c|c|}
\hline & $\begin{array}{l}\text { gyp } \\
\text { GV }\end{array}$ & $\begin{array}{l}\mathrm{ca} \\
\mathrm{N}\end{array}$ & $\begin{array}{l}\text { an } \\
\mathrm{N}\end{array}$ & $\begin{array}{l}\text { go } \\
\text { GV }\end{array}$ & $\begin{array}{l}\text { go } \\
\text { GV }\end{array}$ & $\begin{array}{l}\text { sd } \\
\mathrm{L}\end{array}$ & $\begin{array}{l}\text { sd } \\
\mathrm{GV}\end{array}$ & $\begin{array}{l}\mathrm{sd} \\
\mathrm{N}\end{array}$ & $\begin{array}{l}\mathrm{sd} \\
\mathrm{N}\end{array}$ & $\begin{array}{l}\text { mag } \\
\text { GV }\end{array}$ & $\begin{array}{l}\text { il } \\
\text { GV }\end{array}$ & $\begin{array}{l}\text { clay } \\
\text { L }\end{array}$ \\
\hline $\mathrm{SiO}_{2}$ & 0.10 & 0.52 & 0.08 & 0.14 & 3.00 & 0.05 & 0.51 & 2.15 & 0.31 & 0.06 & 0.01 & 40.2 \\
\hline $\mathrm{TiO}_{2}$ & - & - & - & - & - & - & - & - & - & 14.5 & 50.5 & - \\
\hline $\mathrm{Al}_{2} \mathrm{O}_{3}$ & - & 0.05 & - & - & 0.62 & - & - & - & 0.23 & 2.21 & 0.17 & 3.2 \\
\hline $\mathrm{Cr}_{2} \mathrm{O}_{3}$ & - & - & - & - & - & - & 0.25 & 0.14 & 0.15 & 1.49 & 0.29 & - \\
\hline $\mathrm{FeO}$ & 0.35 & 1.10 & 0.23 & - & - & 36.9 & 48.9 & 39.3 & 24.5 & 48.1 & 45.4 & 32.1 \\
\hline $\mathrm{Fe}_{2} \mathrm{O}_{3}$ & - & - & - & 86.1 & 70.8 & - & - & - & - & 32.7 & 1.45 & - \\
\hline $\mathrm{MnO}$ & - & - & - & - & - & 4.12 & 1.26 & 1.05 & 19.9 & 0.46 & 0.81 & 1.1 \\
\hline $\mathrm{MgO}$ & - & - & 0.15 & - & 0.22 & 0.28 & 3.17 & 13.8 & 7.00 & 0.42 & 1.20 & 10.8 \\
\hline $\mathrm{NiO}$ & - & - & - & - & - & - & - & - & - & - & 0.10 & - \\
\hline $\mathrm{CaO}$ & 41.9 & 52.4 & 44.1 & 0.07 & 0.22 & 18.0 & 5.45 & 2.32 & 0.23 & 0.07 & 0.09 & 1.4 \\
\hline $\mathrm{Na}_{2} \mathrm{O}$ & - & 0.09 & 0.19 & - & 0.35 & 0.85 & 1.06 & 0.27 & 1.65 & - & - & 0.5 \\
\hline $\mathrm{K}_{2} \mathrm{O}$ & - & - & 0.04 & - & 0.13 & 0.03 & 0.15 & - & 0.39 & - & - & 0.4 \\
\hline $\mathrm{P}_{2} \mathrm{O}_{5}$ & - & 40.6 & - & - & - & - & - & 0.09 & - & - & - & - \\
\hline $\mathrm{SO}_{3}$ & 48.0 & - & 55.4 & - & - & - & - & 0.11 & 2.12 & - & - & - \\
\hline $\mathrm{F}$ & - & 0.49 & - & - & - & - & - & - & - & - & - & - \\
\hline $\mathrm{Cl}$ & - & 4.71 & - & 0.04 & 4.54 & 0.15 & 0.42 & 0.25 & 1.04 & - & - & - \\
\hline $\mathrm{CO}_{2}^{\mathrm{a}}$ & - & - & - & - & - & 39.6 & 38.8 & 40.6 & 42.5 & - & - & - \\
\hline \multirow[t]{6}{*}{ Total } & 90.4 & $98.7^{\mathrm{b}}$ & 100.2 & 86.4 & 79.9 & 100.0 & 100.0 & 100.0 & 100.0 & $100.0^{c}$ & $100.0^{\mathrm{c}}$ & 89.7 \\
\hline & & & & $\mathrm{mol} \%$ & & & & & & $\%$ uv, \%mag & $\%$ il, $\% \mathrm{hm}$ & \\
\hline & & & & Calcite & & 35.8 & 11.1 & 4.2 & 0.4 & $37.2,62.8$ & $98.6,1.4$ & \\
\hline & & & & Magnesite & & 0.8 & 9.0 & 29.4 & 16.9 & & & \\
\hline & & & & Siderite & & 57.0 & 77.8 & 64.7 & 45.4 & & & \\
\hline & & & & Rhodochrosite & & 6.5 & 2.0 & 1.7 & 37.2 & & & \\
\hline
\end{tabular}

$\mathrm{GV}=$ Governador Valadares, $\mathrm{N}=$ Nakhla, $\mathrm{L}=$ Lafayette, $\mathrm{sd}=$ siderite, go = goethite, gyp= gypsum, an= anhydrite, ca = chlorapatite, il = ilmenite, $u v=$ ulvöspinel, mag $=$ Ti-magnetite, $\mathrm{hm}=$ haematite.

${ }^{\mathrm{a}} \mathrm{CO}_{2}$ calculated by difference.

${ }^{\mathrm{b}}$ Total corrected for $\mathrm{O}$ equivalent of $\mathrm{F}$ and $\mathrm{Cl}$.

${ }^{c} \mathrm{Fe}_{2} \mathrm{O}_{3}$ and mag-uv/il-hm end members calculated on the basis of surplus to 24 or four cations followed by normalisation. All analyses WDS except Lafayette clay, which is EDS.

Table 3

Trace element analyses (ppm)

\begin{tabular}{llllllllllllllllllllll}
\hline \multicolumn{2}{l}{ Identifier } & $\mathrm{Rb}$ & $\mathrm{Sr}$ & $\mathrm{Zr}$ & $\mathrm{Nb}$ & $\mathrm{Ba}$ & $\mathrm{La}$ & $\mathrm{Ce}$ & $\mathrm{Pr}$ & $\mathrm{Nd}$ & $\mathrm{Sm}$ & $\mathrm{Eu}$ & $\mathrm{Gd}$ & $\mathrm{Tb}$ & $\mathrm{Dy}$ & $\mathrm{Ho}$ & $\mathrm{Y}$ & $\mathrm{Th}$ & $\mathrm{U}$ \\
\hline sd & $\mathrm{GV} 24$ & 31.4 & 152 & 8.29 & 3.30 & 31.1 & 5.20 & 8.95 & 1.13 & 4.42 & 0.88 & 0.12 & 0.59 & 0.10 & 1.04 & 0.27 & 2.69 & - & - \\
sd & $\mathrm{GV8}$ & 38.2 & 96 & 2.29 & 0.62 & 106.0 & 8.88 & 18.7 & 2.43 & 8.82 & 1.78 & 0.43 & 2.26 & 0.17 & 1.52 & 0.21 & 3.68 & - & - \\
gyp & $\mathrm{GV9}$ & 12.4 & 623 & 0.93 & 0.16 & 97.2 & 22.4 & 51.1 & 6.79 & 28.1 & 5.34 & 0.58 & 3.40 & 0.54 & 2.64 & 0.57 & 9.40 & - & - \\
sd & Laf2 & 4.3 & 983 & 0.43 & 0.02 & 25.4 & 0.56 & 3.44 & 0.11 & 0.71 & 0.03 & 0.02 & 0.25 & 0.01 & 0.03 & 0.01 & 0.72 & - & - \\
sd & Laf3 & 14.2 & 704 & 1.16 & 0.13 & 16.8 & 1.94 & 6.54 & 0.38 & 1.32 & 0.18 & - & 0.05 & 0.02 & - & 0.01 & 0.63 & - & - \\
sd & Laf4 & 34.5 & 1025 & 1.34 & 1.08 & 37.5 & 1.08 & 2.51 & 0.13 & 1.99 & 0.19 & 0.23 & 0.33 & 0.05 & 0.07 & 0.03 & 1.75 & - & - \\
sd & Laf5 & 46.3 & 1050 & 1.63 & 0.98 & 33.3 & 1.33 & 2.87 & 0.25 & 1.58 & 0.35 & 0.17 & 0.55 & 0.03 & 0.27 & 0.06 & 1.87 & - & - \\
sd & Laf6 & 0.1 & 896 & 0.31 & 0.05 & 21.8 & 0.38 & 1.21 & 0.19 & 0.76 & - & - & 0.26 & 0.01 & 0.02 & 0.01 & 0.70 & - & - \\
sd & Laf7 & 2.8 & 812 & 0.31 & 0.19 & 32.2 & 0.50 & 0.93 & 0.06 & 0.38 & 0.02 & - & 0.29 & - & 0.02 & 0.02 & 0.78 & - & - \\
clay & Laf8 & 7.0 & 641 & 1.03 & 0.15 & 16.7 & 0.87 & 2.73 & 0.71 & 1.32 & 0.29 & 0.08 & - & - & - & 0.04 & 1.49 & - & - \\
clay & Laf9 & 17.7 & 151 & 1.08 & 0.11 & 9.3 & 1.77 & 2.55 & 0.22 & 1.02 & 0.08 & 0.28 & 1.24 & 0.04 & 0.09 & 0.04 & 0.96 & - & - \\
clay & Laf10 & 10.3 & 929 & 2.28 & 0.09 & 36.6 & 1.90 & 2.44 & 0.23 & 1.52 & 0.13 & 0.25 & 0.75 & - & 0.07 & 0.24 & 1.62 & - & - \\
ca & Laf & 0.11 & 447 & 2.66 & 0.12 & 13.8 & 383 & 755 & 81.1 & 319 & 40.1 & 8.36 & 25.3 & 5.33 & 14.15 & 2.36 & 37.8 & 10.4 & 3.5 \\
\hline
\end{tabular}

$\mathrm{GV}=$ Governador Valadares, Laf = Lafayette; sd= siderite, gyp= gypsum, ca=chlorapatite. Errors $(1 \sigma) 50-70 \%$ at $0.01 \mathrm{ppm}, 15-$ $20 \%$ at $0.1 \mathrm{ppm}, 5 \%$ at $1 \mathrm{ppm}$. 


\section{Results}

\subsection{Mineral assemblages}

Lafayette is found to contain significant amounts of Ca-rich siderite (grains $\leq 100 \mu \mathrm{m}$ ) situated along fractures, often as a result taking a rhombohedral shape, and smectite/illite veins within olivine (Fig. 1A). Chlorapatite is also abundant, mainly within interstitial areas, but no sulphate grains have been found.

In contrast, siderite grains in Governador Valadares are located in interstitial areas within the meteorite, often associated with Ti-rich magnetite or ilmenite, and range in size up to $30 \mu \mathrm{m}$ length. Fig. 1B shows a lamella of ilmenite, less than $5 \mu \mathrm{m}$ wide, present within a $30 \mu \mathrm{m}$ siderite grain. One Ti-magnetite grain (Fig. 1C) encloses a rhombohedral siderite grain and lesser amounts of nonstoichiometric feldspathic glass. Another grain of siderite is located at the upper margin, and partially enclosed, within the same magnetite. Veins of goethite occur in the interstitial areas, in one case crosscutting a grain of gypsum (Fig. 1D). Gypsum or anhydrite is sometimes adjacent to siderite but veins of gypsum up to $450 \mu \mathrm{m}$ long and less than $5 \mu \mathrm{m}$ wide are also found within the augite and olivine (Fig. 1E). Minor chlorapatite is present in the interstitial areas.

Nakhla contains halite, siderite, anhydrite, chlorapatite and veins of sulphate that are probably gypsum. This assemblage has been described elsewhere [20]. Like the siderite in Governador Valadares, the siderite (grains $\leq 50 \mu \mathrm{m}$ ), anhydrite, chlorapatite and halite occur within interstitial areas together with occasional veins of goethite. Some of the siderite grains in Nakhla are also intergrown with magnetite-ilmenite and interstitial pyroxene. The halite is frequently adjacent to or enclosing siderite or anhydrite and is present in massive segregations up to $400 \mu \mathrm{m}$ diameter or as veins (Fig. 1F). This suggests that the halite crystallised after the other minerals. The evaporite mineral assemblages found in each of the three nakhlites are summarised in Table 1 .

\subsection{Mineral compositions}

Representative mineral compositions for the three nakhlites are given in Table 2. Siderite in Lafayette has the most $\mathrm{Ca}$-rich and $\mathrm{Mg}$-poor compositions of the three meteorites with a range of compositions $\mathrm{CaCO}_{3}$ 21.6-36.8, $\mathrm{MnCO}_{3} 4.2-$ 35.3, $\mathrm{MgCO}_{3}$ 0.1-1.6, $\mathrm{FeCO}_{3}$ 27.4-67.0 $\mathrm{mol} \%$ (20 analyses). Governador Valadares has lower $\mathrm{Ca}$ and higher $\mathrm{Mg}$ contents with the range $\mathrm{CaCO}_{3}$ 3.6-11.1, $\mathrm{MnCO}_{3}$ 1.1-2.1, $\mathrm{MgCO}_{3}$ 9.0-29.2, $\mathrm{FeCO}_{3} \quad 64.3-77.8 \mathrm{~mol} \%$ (12 analyses). Nakhla

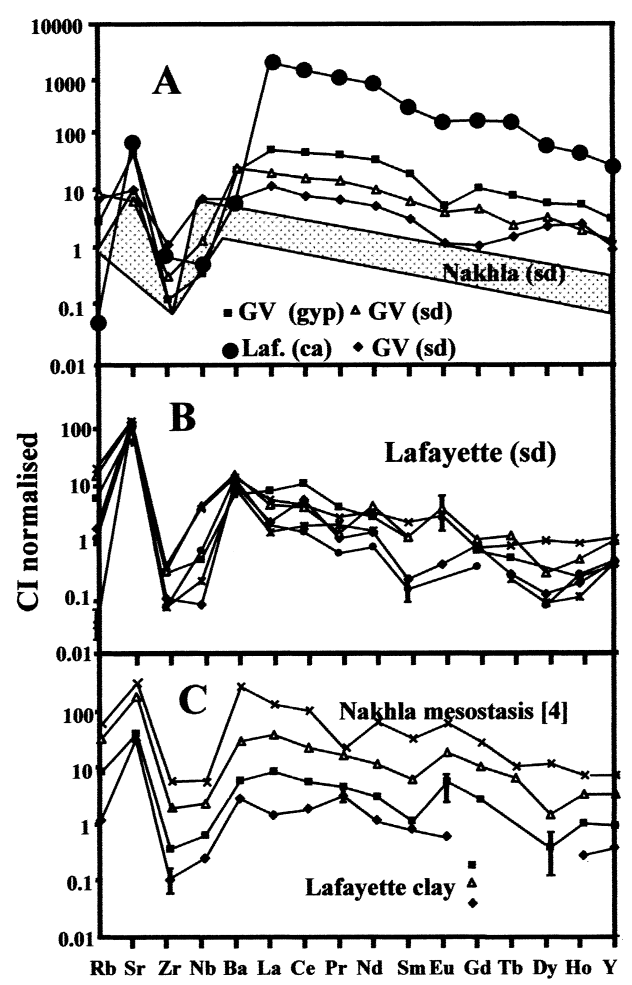

Fig. 3. Trace element abundances in the evaporite minerals. Vertical bars show typical larger $1 \sigma$ errors. $G V=$ Governador Valadares, Laf. $=$ Lafayette; $\mathrm{ca}=$ chlorapatite,$\quad \mathrm{sd}=$ siderite, gyp = gypsum. (A) One gypsum analysis from Governador Valadares (squares), two siderite analyses and one chlorapatite (filled circles). Stippled area is field of Nakhla siderite trace element abundances [20]. (B) Five siderite grains from Lafayette. (C) Three clay vein analyses from Lafayette. Trace element abundances of a Nakhla low density separate (crosses) [4] are also plotted to give an indication of relative trace element abundances of the fluid that had dissolved such interstitial silicate and from which the evaporite mineral assemblage crystallised. 
has the lowest $\mathrm{Ca}$ and highest $\mathrm{Mg}$ and $\mathrm{Mn}$ contents. $\mathrm{CaCO}_{3}$ 0.1-5.7, $\mathrm{MnCO}_{3} 1.0-39.9, \mathrm{MgCO}_{3}$ 2.0-40.9, $\mathrm{FeCO}_{3}$ 23.2-87.0 $\mathrm{mol}_{\%} \%$ (41 analyses from 32 grains). The Nakhla siderite also has high and low $\mathrm{MnCO}_{3}$ groupings ( $\geq 30 \mathrm{~mol} \%$ and $\leq 20 \mathrm{~mol} \%$ ). These analyses are plotted on $\mathrm{Ca}-\mathrm{Mg}-\mathrm{Fe}$ and $\mathrm{Mn}-\mathrm{Mg}-\mathrm{Fe}$ and ternary diagrams (Fig. 2A,B). Another feature of the siderite compositions is the high content of $\mathrm{Cl}$ present within them $(\leq 1 \mathrm{wt} \%$ in the case of Governador Valadares). Table 2 also gives gypsum and goethite compositions. The goethite in Nakhla and Governador Valadares contains $\leq 4.9 \mathrm{wt} \% \mathrm{Cl}$.

Ti-magnetite in Governador Valadares has the range of compositions (based on seven mineral pairs) ulvöspinel 37-57, magnetite 43-63 mol\% and ilmenite lamellae within the Ti-magnetite grains are ilmenite $_{93.6-100}$ haematite $_{0-6.4} \mathrm{~mol}^{\%}$, and these compositions are similar to those reported for Nakhla and Lafayette [27]. These mineral pair compositions can be used to constrain a subsolidus temperature and oxidation state of ilmenite exsolution from the magnetite-ulvöspinel solid solution [28]. The temperature and oxygen fugacities are $700-750^{\circ} \mathrm{C},-\log _{10} f \mathrm{O}_{2}=16-19$, lying close to the quartz-fayalite-magnetite buffer conditions.

\subsection{Trace elements}

Trace element abundances for siderite, gypsum, clay and chlorapatite are given in Table 3 and Fig. 3A-C. Siderite in Governador Valadares has the highest trace element abundances of the three meteorites with $\mathrm{Rb}, \mathrm{Sr}, \mathrm{Ba}$ and LREE (La $22-38 \times \mathrm{CI})>\mathrm{Zr}, \quad \mathrm{Nb}, \quad \mathrm{HREE}$ and $\mathrm{Y}$ (1.7$2.4 \times \mathrm{CI})$. Siderite in Lafayette has flatter REE profiles and lower levels of enrichment (La 1.6$8.3 \times \mathrm{CI}$, Y $0.41-1.20 \times \mathrm{CI}$ ) than Governador Valadares. The Lafayette compositions overlap with the abundances determined previously for Nakhla siderite and anhydrite [20]. The Lafayette siderite has the highest $\mathrm{Sr}$ abundances $(90-130 \times \mathrm{CI})$ of the three meteorites, consistent with its high $\mathrm{Ca}$ contents.

Gypsum in Governador Valadares has a smooth abundance pattern, like that of the siderite but with a higher enrichment of trace ele- ments $(\mathrm{La} 95 \times \mathrm{CI}, \mathrm{Y} 6 \times \mathrm{CI})$ and a slight negative $\mathrm{Eu}$ anomaly $\left(\mathrm{Eu} / \mathrm{Eu}^{*}=0.34\right)$. Clay veins in Lafayette show the same general abundance pattern and similar levels of enrichment to the siderite in the meteorite ( $\mathrm{La} 3.7-18.8 \times \mathrm{CI}$, Y 0.96 $1.25 \times \mathrm{CI})$. There are no consistent $\mathrm{Eu}$ anomaly patterns in the siderite grains. For instance, Governador Valadares has none, but two of the Lafayette grains do show $\mathrm{Eu} / \mathrm{Eu}^{*}$ ratios $>1(1.9,3)$ and these anomalies are greater than the $1 \sigma$ error bars. Similarly, one of the Lafayette clay analyses has a $\mathrm{Eu} / \mathrm{Eu}^{*}$ ratio of $4.8 \mathrm{Eu}$ anomalies are, therefore, variable between the different analysed grains.

Chlorapatite has a steep abundance pattern and much higher levels of enrichment, with $2300 \times \mathrm{CI}$ for $\mathrm{La}$ and $34 \times \mathrm{CI}$ for $\mathrm{Y}$. Some $\mathrm{F}$ was detected $(211 \times \mathrm{CI})$ but no $\mathrm{H}^{+}$ions above background levels, indicating that the chlorapatite is anhydrous. The trace element abundances of a low density separate from Nakhla (a mixture of feldspar and glass) are shown in Fig. 3C [4]. It has a similar abundance pattern to the phases studied here but, apart from the chlorapatite, higher overall enrichments $(\mathrm{La} 67 \times \mathrm{CI})$. It only contains a small $\mathrm{Eu}$ anomaly $\left(\mathrm{Eu} / \mathrm{Eu}^{*}=1.9\right)$.

\section{Discussion}

\subsection{Mineral assemblages and trace elements}

Although more sections of Nakhla than the other two meteorites have been examined, accurate representations of the minerals present have probably been described (Table 1). For instance, at least traces of halite are found in most sections of Nakhla, so its absence in the other two meteorites is likely to be genuine. The clearest new evidence for a low temperature origin of the evaporite mineral assemblages in the nakhlites is shown by the fracture filling clay minerals (undifferentiated mixture of smectite/illite) and siderite within Lafayette. In a previous model [20] we interpreted the relatively complex textures of siderite and associated phases in Nakhla to indicate the possibility of an origin from residual melt at elevated temperatures. However, in the light of 
our new data it seems likely that the alternative explanation involving fracture filling or the replacement of pre-existing high temperature phases is correct. In this paper we therefore consider a low temperature model, with crystallisation from a brine, for the salt assemblages in the three meteorites.

It is possible to infer a crystallisation sequence from a brine for the minerals studied here. Clay minerals are likely to have formed before the anhydrite and halite, otherwise the latter two minerals might have been hydrated or dissolved. The association of Ca-siderite with clay minerals within the olivine grains suggests that it formed at an earlier stage than the interstitial Ca-poor siderite. Considering the three nakhlites together, the general order of precipitation is clay mineral veins+ Ca-siderite, gypsum, anhydrite, halite. Progressively more $\mathrm{Mg}$-, $\mathrm{Mn}$-rich siderite crystallises following the initial Ca-siderite growth. There may be two separate generations of phosphates - a low temperature one which includes the chlorapatite associated with halite [20] and also an igneous/ subsolidus one [7]. The trace element chemical analysis of the chlorapatite analysed here is similar to that of chlorapatite shown to be igneous by [29]. An igneous origin is supported by the anhydrous composition determined here, although the analyses of [29] had negative Eu anomalies. The distinction between different generations of phosphate remains problematic and it is not certain how apatite precipitation relates to the evaporite mineral assemblage discussed here. The reason for the association between magnetite or ilmenite and the salt minerals in Governador Valadares is not clear either but may simply be coincidental because both occur in the interstitial areas. There is no clear evidence for replacement of magnetite by siderite.

The trace element abundances of the salt minerals in the three nakhlites are characterised by LREE $>$ HREE. Complexing of the REE in brines is associated with HREE enrichment [30], thus this cannot be the control on the trace element abundances. The higher abundances of trace elements with large ionic radii $(\mathrm{Rb}, \mathrm{Zr}, \mathrm{Nb}$, LREE) are also inconsistent with a partitioning control based on ionic radii because the optimal

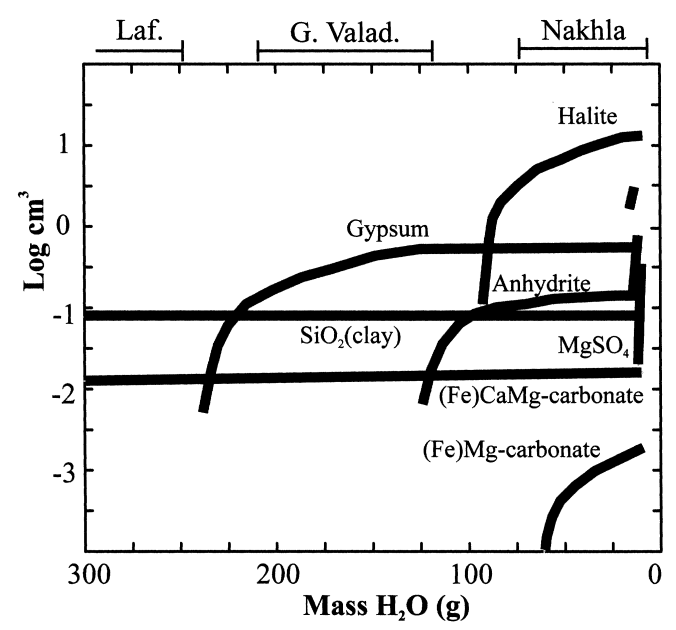

Fig. 4. Progressive evaporation model for the three nakhlites. Volume of minerals precipitated is plotted against remaining mass of water (starting from $1000 \mathrm{~g}$ ). Composition of starting water was taken as terrestrial seawater but with $\mathrm{Mg}=1500 \mathrm{mg} / \mathrm{kg}$, no $\mathrm{K}$ and $\mathrm{SiO}_{2}(\mathrm{aq})=200 \mathrm{mg} / \mathrm{kg}$. Concentration ranges of $\mathrm{HCO}_{3}^{-}=61-800 \mathrm{mg} / \mathrm{kg}$ and $\mathrm{pCO}_{2}(\mathrm{~g})=30$ $100 \mathrm{mbar}$, after [38,39], give the same pattern of evaporation. This model uses the Geochemist's Workbench program, which has the data base of [35]. In this figure the carbonate precipitated is assumed to be Fe-rich although $\mathrm{Fe}$ bearing species are not listed within the actual program. Similarly it is assumed that the free silica predicted by the program can have reacted with olivine within the nakhlites to form clay, or alternatively, have precipitated as clay from a silica-rich gel. The clay and $\mathrm{Fe}, \mathrm{Ca}, \mathrm{Mg}$ bearing carbonate assemblage formed at a low extent of evaporation ( $>25 \%$ water remaining) corresponds to the siderite and clay veins present in Lafayette. The addition of gypsum (at around 15-20\% water remaining) is similar to the Governador Valadares assemblage, and the presence of more $\mathrm{Mg}$-rich carbonate, halite, anhydrite and $\mathrm{Mg}$-sulphate [14] once evaporation is nearly complete $(<10 \%$ remaining) corresponds to Nakhla.

ionic radius for substitution into calcite is $0.96 \AA$ [31], which is similar to the radii of the middle and HREE. The Lafayette siderite, which is the most Ca-rich, does not have the highest HREE contents of the three meteorites. Within saline fluids (e.g. with ionic strengths $\geq 0.7 \mathrm{~mol} \mathrm{~kg}^{-1}$ ) the REE can be present as free metal ion species [32]. Therefore, the trace element patterns reflect fluid composition and the similarity in the trace element abundances of the clay mineral veins and the siderite suggests that they were both derived from the same LREE-enriched brines.

Treiman and Lindstrom [33] suggested that the 
major element composition of the clay mineral veins in Lafayette could be modelled as an altered mixture of the meteorite's olivine $(50 \%)$, mesostasis $(40 \%)$ and water $(10 \%)$. This would imply that the trace element composition of the fluid from which the clay and salt minerals formed was dominated by the dissolved interstitial feldspar, feldspathic glass and silica polymorphs, like the low density separate [4] shown in Fig. 3C. Therefore the trace element contents of the fluid, and thus those of evaporitic minerals which crystallised from it, may represent a dissolved fraction of interstitial, igneous silicate from the nakhlites. The absence of consistent positive Eu anomalies in the nakhlite salt minerals may be because interstitial silicate in the nakhlites has only a small Eu anomaly [4] and also as a result of oxidising conditions in a near surface, martian setting. However, it is not certain whether the composition of the fluid was determined entirely as a closed system within the nakhlite parent rocks because similar compositions could have been produced through the transport of cations from other igneous rocks in the martian crust.

\subsection{Solubility controls on the evaporite mineral assemblages}

The order of solubility of salts in cold water [34] is: chlorapatite $<\mathrm{CaCO}_{3}<\mathrm{FeCO}_{3}=\mathrm{MnCO}_{3}$ $<\mathrm{MgCO}_{3} \ll$ anhydrite $<$ gypsum $\ll$ halite. The evaporite assemblages demonstrate a solubility trend Lafayette only has minerals (siderite and, possibly, chlorapatite) with relatively low solubility in water at low temperature, Nakhla also contains minerals with high solubilities and Governador Valadares includes those of intermediate solubility. Decreasing $\mathrm{Ca}$ and increasing $\mathrm{Mg}$ contents of siderite from Lafayette to Nakhla are also consistent with a solubility trend. The presence of the least soluble, Ca-rich siderite along clay mineral veins within Lafayette and, in contrast, the more soluble Mg-rich siderite within interstitial areas of the other two nakhlites might also be a result of this control.

Only the presence of anhydrite and the uncertainty involving the possible two generations of chlorapatite disrupt the general solubility trends between and within the three nakhlites. In practice, the high ionic strength of the brine means that the actual solubility values are unknown but the relative trend between the minerals is likely to be correct. This solubility control suggests a model of progressive evaporation is applicable to the nakhlites.

\subsection{Model of progressive evaporation}

The nature of the mineral assemblages described here implies that the brine from which they could have crystallised was similar to the terrestrial $\mathrm{Na}-\mathrm{K}-\mathrm{Mg}-\mathrm{Ca}-\mathrm{SO}_{4}-\mathrm{Cl}-\mathrm{H}_{2} \mathrm{O}$ type which is found in a variety of continental or seawater environments [35,36]. Similar, although probably less saline, acidic brines have been described from the Palo Duro basin in Texas $[32,37]$. The REE abundances of aquifer samples from Palo Duro were related to interactions with clastic and carbonate sediments in the surrounding country rocks.

However, the nakhlite fluid must have had a low $\mathrm{K}$ content and significant amounts of $\mathrm{SiO}_{2}$ and $\mathrm{Fe}$, derived by dissolution of mesostasis and olivine, possibly in a near surface setting. This fluid is likely to have remained at low $\mathrm{pH}$ and negative alkalinity throughout its evolution. Schaeffer [38] modelled the geochemical evolution of the martian hydrosphere. Although it was primarily concerned with the hypothesis of a northern palaeo-ocean, much of the model is applicable here (e.g. lower limits for $\mathrm{HCO}_{3}^{-}$concentration in water that had exchanged with $\mathrm{CO}_{2}$ in the martian atmosphere). Fig. 4 shows the results of a progressive evaporation model which uses 'Geochemist's Workbench' software. Following [38,39], parameter ranges used were $\mathrm{pCO}_{2}(\mathrm{~g})=30-100 \mathrm{mbar}, \mathrm{HCO}_{3}^{-}=61-800 \mathrm{mg} / \mathrm{kg}$ and most of the starting cation concentrations were those of terrestrial seawater. The fluid temperature was $10-25^{\circ} \mathrm{C}$. However, $\mathrm{K}^{+}$was set to a negligible value and $\mathrm{Mg}$ and $\mathrm{SiO}_{2(\mathrm{aq})}$ to higher values 1500 and $200 \mathrm{mg} / \mathrm{kg}$ - in order to make the calculated mineral assemblages more consistent with those present in the nakhlites. For similar reasons, Treiman and Lindstrom [33] also suggested that low temperature fluids in the nakh- 
lites had been Mg-rich. The same, or closely similar, results were obtained across the range of atmospheric and fluid parameters above.

The results of the model calculation in Fig. 4 show free $\mathrm{SiO}_{2}$. As there is no such phase associated with the evaporite assemblages, it is likely that this reacted with olivine and water to form the clay mineral veins. Alternatively it could have precipitated as part of a silicate gel within cracks of the olivine grains [33], subsequently forming the smectite/illite. The model of [35], which includes the species data base upon which 'Geochemist's Workbench' is based does not include either $\mathrm{P}, \mathrm{Fe}$ or $\mathrm{Mn}$. The lack of Fe causes the calculated carbonate composition to be dolomite rather than siderite. However, in practice the high $\mathrm{Fe}$ concentration of the low temperature fluid considered here is consistent with siderite as the actual phase and so this is shown in Fig. 4. Catling [39] also suggested, on the basis of a thermodynamic model, that siderite would initially precipitate from fluids derived from weathered martian rocks.

The model (starting with $1000 \mathrm{~g}$ of brine) can be used to trace the approximate extent of evaporation that the fluid had undergone in the parent rock of each of the three meteorites. The free $\mathrm{SiO}_{2}$ (giving clay) and carbonate bearing assemblage where $>25 \%$ volume of the water remains corresponds to Lafayette; the gypsum and anhydrite, free $\mathrm{SiO}_{2}$ (clay), carbonate assemblage where $20 \%$ of the water remains corresponds to Governador Valadares; the halite, anhydrite, Mg-rich carbonate, clay assemblage in Nakhla suggests that $<10 \%$ of the water remained in its parent rock. The presence of Mg-sulphate traces in Nakhla [14] might mean that evaporation of the fluid by that stage was almost complete, with $<5 \%$ water remaining. Precipitation of Ca-rich carbonate followed by more $\mathrm{Mg}$-carbonate and gypsum is a common trend within evolving brines [40]. In one section of Nakhla, halite was found to be $>10$ times more abundant than other salt phases [20] so the relative volumes in Fig. 4 are broadly consistent with the petrographic observations. Fluids could easily have migrated as groundwater through the parent rocks in the upper few tens of metres of the martian crust.

\subsection{Martian setting}

The nature of the evaporite mineral assemblages in the nakhlites suggests an origin through occasional flooding episodes. As Warren [22] argued in an evaporitic model for carbonates within ALH84001, protracted exposure to water would have caused extensive alteration of pyroxene. Water probably ponded in areas of enclosed drainage such as craters [41] or low-lying flood plains near the northern plains/southern highlands boundary. Some ponded water would have seeped as groundwater into the upper layers of the martian crust. The nakhlites may have originated as igneous layers within a near surface setting underneath an area such as a flood plain or crater where water was able to pond. The acidic groundwater percolated from the ground surface through the nakhlites, dissolving mesostasis and other silicate phases, subsequently precipitating the salt minerals due to evaporation.

Progressive evaporation requires that the past martian climate ( $\leq 1.3 \mathrm{Ga}$ in this case) was warmer and above freezing point for more than just summer days during perihelion as at present. Changes in the obliquity of Mars over the last $1.3 \mathrm{Ga}$ on timescales of $10^{5}-10^{7}$ years caused major variations in the distribution of solar insolation over the planet and warmer periods $[42,43]$. Another factor affecting surface temperatures was the thickness of the atmosphere which may have been $>70$ mbar $[38,39,44,45]$. The localised melting of ice due to volcanic activity [46] could also precipitate brief flooding episodes during this relatively recent stage in the planet's history. Evaporation of flood waters may have led to the formation of hard pans, such as those thought to be present in layers within the flood plains around Chryse [47].

Primitive life may have existed on evaporite deposits as they have experienced the past presence of liquid water. Hypersaline environments can support bacterial life (e.g. [48]). Of the various geological environments, e.g. hydrothermal springs, karst topography, where any life may have occurred, this one probably has the strongest current evidence for its existence both from the information provided here from meteorites and 
also remote sensing data [41]. The Mars Beagle 2 Lander for $2003 / 4$ is designed to test accurately for signs of life such as methane and ${ }^{12} \mathrm{C}$-enriched deposits [25,26]. The identification of suitable evaporite or hard pan areas using data from the current Mars missions may enable such areas to be considered as a landing site.

\section{Conclusions}

The three nakhlite meteorites Lafayette, Governador Valadares and Nakhla contain an assemblage of minerals that together record the progressive evaporation of a brine through their parent igneous rocks on Mars. Lafayette contains Ca-rich siderite situated along clay mineral (smectite/illite) veins within olivine. This records the initial precipitation of minerals from the brine. With more extensive evaporation of the brine the more soluble clay minerals, Ca-poor siderite and gypsum and anhydrite crystallised in the parent rock of Governador Valadares. Nakhla contains the final products of the evaporating brine: clay minerals, $\mathrm{Mg}-$, $\mathrm{Mn}$-rich siderite, gypsum veins, anhydrite and halite. Most of the salt minerals in the latter two meteorites are located in interstitial areas. All three meteorites also contain some goethite. Chlorapatite is present in each of the meteorites but its origin is less clear - some of the chlorapatite has an anhydrous composition consistent with an igneous origin but there may also be a separate, low temperature generation. The sequence of salt crystallisation can be modelled as the progressive evaporation of a brine with the composition of terrestrial seawater (but lower $\mathrm{K}$ and higher $\mathrm{SiO}_{2}$ and $\mathrm{Mg}$ ). Lafayette marks the point where $>25 \%$ of the water remains, Governador Valadares $20 \%$ and Nakhla $<10 \%$.

The siderite, gypsum and clay minerals all have LREE $>$ HREE, Y abundances. These patterns are similar to that of Nakhla mesostasis determined by other workers, and suggest that the trace element composition of the salt minerals reflects that of the fluid, which in turn was derived through prior dissolution of mesostasis elsewhere in the parent igneous rocks.
The existence of evaporating groundwaters in the meteorite parent rocks $\leq 1.3 \mathrm{Ga}$ (the crystallisation age of the nakhlites) is consistent with suggestions that ground temperatures on Mars then were above freezing for more of the time than in the present and the atmosphere was thicker (e.g. 30-100 mbar) at least for brief periods. The waters may have originated as floodwaters trapped in areas of in internal drainage such as low-lying flood plains or craters.

\section{Acknowledgements}

This work is funded by PPARC. The trace element analyses were made at the NERC-maintained ion probe facility of Edinburgh University. R. Hinton is thanked for advice on the trace element work. This paper benefited from a constructive review by P.H. Warren.[EB]

\section{References}

[1] R.N. Clayton, T.K. Mayeda, Oxygen isotope studies of achondrites, Geochim. Cosmochim. Acta 60 (1996) 1999 2017.

[2] I.A. Franchi, I.P. Wright, A.S. Sexton, C.T. Pillinger, The oxygen-isotopic composition of Earth and Mars, Meteor. Planet. Sci. 34 (1999) 657-661.

[3] C.A. Wood, C.A. Ashwal, SNC meteorites: Igneous rocks from Mars, Proc. Lunar Planet. Sci. 12B (1981) 13591375 .

[4] N. Nakamura, D.M. Unruh, M. Tatsumoto, R. Hutchison, Origin and evolution of the Nakhla meteorite inferred from the $\mathrm{Sm}-\mathrm{Nd}$ and $\mathrm{U}-\mathrm{Pb}$ systematics and $\mathrm{REE}, \mathrm{Ba}, \mathrm{Sr}, \mathrm{Rb}$, and $\mathrm{K}$ abundances, Geochim. Cosmochim. Acta 46 (1982) 1555-1574.

[5] D.D. Bogard, P. Johnson, Martian gases in an Antarctic meteorite?, Science 221 (1983) 651-654.

[6] I.P. Wright, M.M. Grady, C.T. Pillinger, Chassigny and the nakhlites: Carbon-bearing components and their relationship to Martian environmental conditions, Geochim. Cosmochim. Acta 56 (1992) 817-826.

[7] R.P. Harvey, H.Y. McSween, Petrogenesis of the nakhlite meteorites: Evidence from cumulate mineral zoning, Geochim. Cosmochim. Acta 56 (1992) 1655-1663.

[8] A.H. Treiman, R.A. Barrett, J.L. Gooding, Preterrestrial aqueous alteration of the Lafayette (SNC) meteorite, Meteoritics 28 (1993) 86-98.

[9] A.H. Treiman, M. Norman, D. Mittlefehldt, J. Crisp, 'Nakhlites' on earth: Chemistry of clinopyroxenites from 
Theo's flow, Ontario, Canada, Lunar Planet. Sci. XXVII (1996) 1341-1342.

[10] F.A. Podosek, Thermal history of the nakhlites by the ${ }^{40} \mathrm{Ar} /{ }^{39} \mathrm{Ar}$ method, Earth Planet. Sci. Lett. 19 (1973) 135-144.

[11] C.Y. Shih, L.E. Nyquist, D.D. Bogard, H. Wiesmann, Sm-Nd systematics of nakhlite Governador Valadares, Lunar Planet. Sci. XXVII (1996) 1197-1198.

[12] O. Eugster, A. Weigel, Polnau E, Ejection times of Martian meteorites, Geochim. Cosmochim. Acta 63 (1997) 2749-2758.

[13] J.R. Ashworth, R. Hutchison, Water in non-carbonaceous stony meteorites, Nature 256 (1975) 714-715.

[14] J.L. Gooding, S.J. Wentworth, M.E. Zolensky, Aqueous alteration of the Nakhla meteorite, Meteoritics 26 (1991) 135-143.

[15] M.M. Grady, I.P. Wright, C. Douglas, C.T. Pillinger, Carbonates in martian meteorites - a reappraisal, Meteoritics 30 (1995) 511-512.

[16] J.M. Saxton, I.C. Lyon, G. Turner, Oxygen-isotopic composition of Nakhla siderite: Implications for martian volatiles, Meteor. Planet. Sci. 33 (Suppl.) (1998) A172.

[17] E.P. Vicenzi, J. Eiler, Oxygen-isotopic composition and high resolution secondary ion mass spectrometry imaging of Martian carbonate in Lafayette meteorite, Meteor. Planet. Sci. 33 (Suppl.) (1998) A159-A160.

[18] R.H. Carr, M.M. Grady, I.P. Wright, C.T. Pillinger, Martian atmospheric carbon dioxide and weathering-products in SNC meteorites, Nature 314 (1985) 248-250.

[19] E. Chatzitheodoris, G. Turner, Secondary minerals in the Nakhla meteorite, Meteoritics 25 (1990) 354.

[20] J.C. Bridges, M.M. Grady, A halite-siderite-anhydritechlorapatite assemblage in Nakhla: Mineralogical evidence for evaporites on Mars, Meteor. Planet. Sci. 34 (1999) 407-416.

[21] J.D. Gilmour, J.A. Whitby, G. Turner, Martian atmospheric xenon contents of Nakhla mineral separates: implications for the origin of elemental mass fractionation, Earth Planet. Sci. Lett. 166 (1999) 139-147.

[22] P.H. Warren, Petrologic evidence for low-temperature, possibly flood evaporitic origin of carbonates in the ALH84001 meteorite, J. Geophys. Res. 103 (1998) 16759-16773.

[23] H.Y. McSween, R.P. Harvey, Brine evaporation: An alternative model for the formation of carbonates in Allan Hills 84001, Meteor. Planet. Sci. 33 (Suppl.) (1998) A103.

[24] V.R. Baker, M.H. Carr, V.C. Gulick, C.R. Williams, M.S. Marley, Channels and valley networks, in: H.H. Kieffer, B.M. Jakosky, C.W. Snyder and M.S. Matthews (Eds.), Mars, University of Arizona Press, Tucson, AZ, 1992, pp. 1498-1522.

[25] C.T. Pillinger, M.R. Sims, Beagle 2, a $60 \mathrm{~kg}$ Lander for Mars, Open University, Milton Keynes, 1998.

[26] J.C. Bridges, M.M. Grady, C.T. Pillinger, M.R. Sims, Landing site selection for the Beagle 2 mission to Mars, Meteor. Planet. Sci. 34 (Suppl.) (1999) A19.
[27] A.M. Reid, T.E. Bunch, The nakhlites, part II. Where, when and how?, Meteoritics 10 (1975) 317-324.

[28] A.F. Buddington, D.H. Lindsley, Iron-titanium oxide minerals and synthetic equivalents, J. Petrol. 5 (1964) 310-357.

[29] M. Wadhwa, G. Crozaz, Trace and minor elements in minerals of nakhlites and Chassigny: Clues to their petrogenesis, Geochim. Cosmochim. Acta 59 (1995) 3629-3647.

[30] M. Bau, Rare-earth element mobility during hydrothermal and metamorphic fluid-rock interaction and the significance of the oxidation state of europium, Chem. Geol. 93 (1991) 219-230.

[31] R.F. Denniston, C.K. Shearer, G.D. Layne, D.T. Vaniman, SIMS analyses of minor and trace element distributions in fracture calcite from Yucca Mountain, Nevada, USA, Geochim. Cosmochim. Acta 61 (1997) 1803-1818.

[32] K.H. Johannesson, W.B. Lyons, M.A. Yelken, H.E. Gaudette, K.J. Stetzenbach, Geochemistry of the rare-earth elements in hypersaline and dilute acidic natural terrestrial waters: Complexation behavior and middle rare-earth element enrichments, Chem. Geol. 133 (1996) 125-144.

[33] A.H. Treiman, D.J. Lindstrom, Trace element geochemistry of Martian iddingsite in the Lafayette meteorite, J. Geophys. Res. 102 (1997) 9153-9163.

[34] R.C. Weast (Ed.), CRC Handbook of Chemistry and Physics, CRC Press, Boca Raton, FL, 1981.

[35] C.E. Harvie, N. Møller, J.H. Weare, The prediction of mineral solubilities in natural waters: The $\mathrm{Na}-\mathrm{K}-\mathrm{Mg}-$ $\mathrm{Ca}-\mathrm{H}-\mathrm{Cl}-\mathrm{SO}_{4}-\mathrm{OH}-\mathrm{HCO}_{3}-\mathrm{CO}_{3}-\mathrm{CO}_{2}-\mathrm{H}_{2} \mathrm{O}$ system to high ionic strengths at $25^{\circ} \mathrm{C}$, Geochim. Cosmochim. Acta 48 (1984) 723-752.

[36] W. Stum, J.J. Morgan, Aquatic Chemistry, Wiley, New York, 1996, $1022 \mathrm{pp}$.

[37] D.C. Gosselin, M.R. Smith, E.A. Lepel, J.C. Laul, Rareearth elements in chloride-rich groundwater, Palo Duro Basin, Texas, USA, Geochim. Cosmochim. Acta 56 (1992) 1495-1506.

[38] M.W. Schaeffer, Geochemical evolution of the northern plains of Mars: Early hydrosphere, carbonate development, and present morphology, J. Geophys. Res. 95 (1990) 14291-14300.

[39] D.C. Catling, A chemical model for evaporites on early Mars: Possible sedimentary tracers of the early climate and implications for exploration, J. Geophys. Res. 104 (1999) 16453-16469.

[40] H.P. Eugster, B.F. Jones, Behavior of major solutes during closed-basin brine evolution, Am. J. Sci. 279 (1979) 609-631.

[41] R.D. Forsythe, J.R. Zimbelman, A case for ancient evaporite basins on Mars, J. Geophys. Res. 100 (1995) 5553 5563.

[42] W.R. Ward, Climatic variations on Mars 1. Astronomical theory of insolation, J. Geophys. Res. 79 (1974) 33753395.

[43] B.G. Bills, The rigid obliquity history of Mars, J. Geophys. Res. 95 (1990) 14137-14153.

[44] J.B. Pollack, J.F. Kasting, S.M. Richardson, K. Poliakoff, 
The case for a wet, warm climate on early Mars, Icarus 71 (1987) 203-224.

[45] I.P. Wright, M.M. Grady, C.T. Pillinger, The evolution of atmospheric $\mathrm{CO}_{2}$ on Mars: The perspective from carbon isotope measurements, J. Geophys. Res. 95 (1990) 1478914794.

[46] D. McKenzie, F. Nimmo, The generation of martian floods by the melting of ground ice above dykes, Nature 397 (1998) 231-233.
[47] A.H. Treiman, Near-surface geologic units exposed along Ares Vallis and in adjacent areas: A potential source of sediment at the Mars Pathfinder landing site, J. Geophys. Res. 102 (1997) 4219-4229.

[48] C.D. Litchfield, Survival strategies for microorganisms in hypersaline environments and their relevance to life on early Mars, Meteor. Planet. Sci. 33 (1998) 813-819. 